\title{
観光情報の自動編纂†
}

\section{難波 英嗣＊}

\section{1. はじめに}

旅行会社や政府観光局などが提供している観光ガイ ドブックやWeb上の観光ポータルサイトは，旅行者に とって有益な情報源となっている。しかし，あらゆる 観光地の情報を絶えず更新し続けるのは非常にコスト がかかる，そこで，近年では，自然言語処理，画像処 理, Webマイニング, 地理情報検索など様々な分野 で, 観光情報の自動編篹に関する研究が行われるよう になってきている。本稿では, 自然言語处理分野を中 心に, この研究に関する動向について述べる。著者は, 2012 年 7 月までのこの分野の研究動向をまとめた サーベイ論文を発表している[Nanba 2012]が，本稿 は, このサーベイ論文で取り上げていない研究を紹介 する.

本稿の構成は以下のと扔りである。2 節では, 観光 データベースの自動構築について述べる．３節では， 旅行者の行動分析について述べる．4節では，観光情 報の推薦に関する諸研究を紹介する５節では, 観光 情報にアクセスするための様々なインターフェイスに ついて述べる。6節では，地理情報検索に関する研究 を紹介する。 7 節で本稿をまとめる.

\section{2. 旅行データベースの自動構築}

本節では，テキストデータから旅行データベースを 自動的に構築する研究を紹介する.

\section{1 イベント情報の自動抽出}

岡本ら [岡本2010]は, ライブ演奏などのイベント 情報や短期間の出店情報などを, ブログから自動的に 抽出する手法を提案している。まず，「東京」や「秋葉 原」などの地名をクエリとして，ブログ検索エンジン を用いて，これらのクエリを含むブログエントリを収 集する。次に, 収集したエントリをクラスタリング し, 各クラスタからC-value 法[Frantsi 1996]により

$\dagger$ Automatic Compilation of Travel Information Hidetsugu NANBA

* 広島市立大学大学院 情報科学研究科

Graduate School of Information Sciences, Hiroshima City University
話題の代表語を抽出する。最後に, 各クラスタの代表 語の時事性と地域性の判定を行う。時事性に関して は, 直近の期間に含まれる文書数が集計期間の文書数 に対してどれだけ多いかを検定し，有意に多いものを ホットな話題とみなす。地域性に関しては, 同じ日に 別地域で, 同じ話題の代表語を持つクラスタの数を算 出し, その值が大きい場合は, 地域性の低い話題であ ると判断し，除外する，以上述べた手法により，例え ば以下のようなものがイベント情報として抽出されて いる.

・音楽グループの告知されていないイベント（レミオ ロメンゲリラライブ：渋谷)

・ スポーツイベント(東京レインボーウォーク：台場）

- 展覧会や博覧会のイベント（加賀百万石名品展：池 袋）

藤坂ら [藤坂 2010]は, 代表的なマイクロブログの ひとつであるTwitterに着目し，大量のジオタグ付き tweetを分析して地域イベントを検出する手法を提案 している，藤坂らの手法では，まず，収集したtweet に付与されている緯度, 経度に基づいて, 代表的なク ラスタリング手法のひとつである $\mathrm{k}-$ means 法を用い て $\mathrm{k}$ 個の領域に分割する。次に, 朝, 昼, 夕方，夜な ごの一定の期間ごとに, 各領域における通常時の発言 量 (tweet 数), 人( Twitter ユーザ)の存在量, 人の移 動量を算出しておく，次に，ある日およびタイムスロッ トの, ある領域に打ける発言量, 人の存在量, 人の移 動量を通常時と比較し, 異常活動の発生領域を検知す る。このような領域では, 地域イベントが開催されて いる可能性が高いと考えられ，実際に2010年 7 月 10 日から 7 月20日の tweet集合を用いて, 京都で開催さ れた祇園祭が検知できたことを，実験により確認して いる.

吉田ら [吉田 2009] はブログ記事とWebページを用 いたイベント情報抽出法を提案している。 あらかじめ 選定した21件のイベント名をクエリとして，これらの イベント名を含むブログを収集し，イベント名の前後 に出現する定型表現を, Kiwiアルゴリズム[Tanaka 
2005]を用いて獲得している。その一部を以下に示 す。以下の定型表現に扎いて...の個所がイベント名に 該当する。

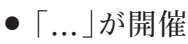

・で開催中の「...」で

・開催される「...」

上記のような定型表現を用い，ことさが (http:// cotosaga.com/) Peventcast (http://clip.eventcast.jp/) といったイベント検索エンジンには登録されていない イベント名が抽出できたことを報告している。

Nanbaら [Nanba 2013:a] は, 祭りや展示会など, 旅 先のイベントに関する情報を新聞とWebから自動抽出 する手法を提案している．新聞にはイベント開催を告 知する記事が掲載されることがある。このような記事 をNanbaらはイベント記事と呼び，新聞記事集合から イベント記事を自動検出し, さらに各イベント記事か ら, イベント名, 開催日時, 開催地(住所), 開催施設 名の 4 種類の項目を抽出している. しかし, 新聞で告 知されるイベントは知名度の高いものに限定される. そこで，新聞には掲載されないようなイベント情報を

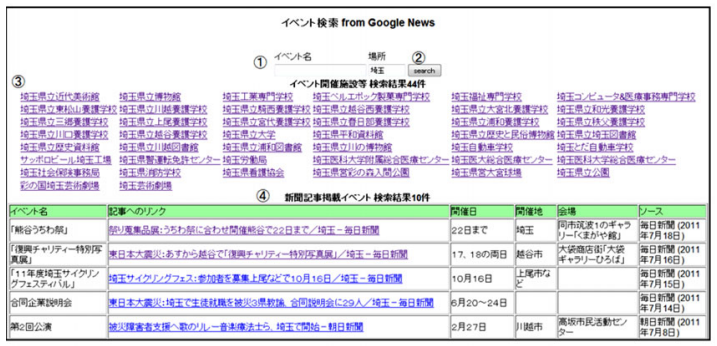

図 1 検索クエリを用いたイベント検索[Nanba 2013:a]

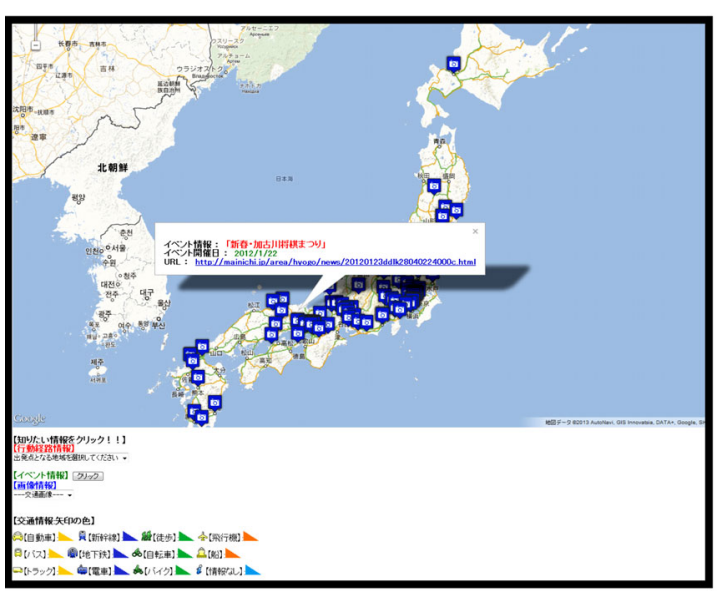

図 2 地図からのイベント検索 [Nanba 2013:a]
Webから収集する。まず，過去10年分の読売新聞記 事から抽出されたイベント記事中の開催施設名を出現 頻度順に並べてその上位30,000件を抽出することによ り, 高頻度でイベントが開催される施設のリストを作 成する。次に，施設名十「イベント」をクエリとして Web検索を行い, 検索結果上位 5 件から, その施設で 開催されるイベントについて記述されたページ（イベ ントWebページ)を自動検出する分類器を作成してい る。イベントWebページかどうかの判定には，「日程」 「開催日」「参加費」など，イベントWebページに良く含 まれる語句を手がかり語として利用している他, URL 中に“event”p“schedule”p“calendar”といった文字 列が含まれるかどうかも, 判定の際に利用している.

こうして抽出されたイベント情報は, 図 1 に示すよ うに，イベント名や開催地をクエリとして検索できる 他, 図 2 に示すように, 地図上から検索することもで きる。

\section{2 旅の経験・ノウハウの自動抽出}

阿部ら [阿部 2009]は，ブログから個人の経験と意 見情報を自動収集し，それらを以下に示す 4 つの観点 から分析することでデータベース化し，個人の経験を 効率的に検索できるシステムを構築している。

（a）トピック：どの利用物に関する経験か

(b) 経験主：経験の主体

(c) 事態タイプ: 経験情報の核となる事態の種類 (ポ ジティブ/ネガティブな出来事・状態・性質, 入 手・利用などの行為)

（d）事実性：(c)の事態の事実性に関する情報（既遂の 事実，未遂の願望，伝聞)

こうして構築されたデータベースの一部は旅に関する ものである。

阿部らの研究と同じく, ブログから個人の経験を抽 出し, データベース化する研究に倉島ら [倉島 2008] のものがある，倉島らは，ブログ中における経験に関 する記述について, 時間, 空間, 動作, 対象, 評価, 感情に関する情報を，それ年れ抽出している。例えば 「昨日，清水寺に紅葉を見に行きました。確かに紅葉 はきれいだったのですが, 観光客で大混雑…後悔しま した。」というブログ中の文について，時間，空間， 動作, 対象, 評価, 感情 $\}=\{$ 昨日, 清水寺, 見る, 紅 葉, きれい, 後悔子が抽出される。これらの抽出結果 を関係データベースに格納し，ここからさらに状況， 行動，主幹との間に存在する関係性を以下のような ルール形式で抽出している。 
Type 1：状況と行動：[空間, 時間] $\rightarrow$ [動作, 対象] (例 1 ) 北海道, 5月～$\rightarrow$ [時間]見る, 桜 [動作, 対象] Type 2 : 状況と主観 : [空間, 時間] $\rightarrow$ [感情] (例 2 ) ディズニーランド [空間] 楽しい[感情]

Type 3 : 行動と主観 : [動作, 対象] $\rightarrow$ [感情] (例 3 ) 引く, おみくじ [動作, 対象 $] \rightarrow$ おっかり [感 情]

\section{Type 4：状況と行動と主観：}

[時間, 空間, 動作, 対象] $\rightarrow$ [感情] [時間, 空間 $] \rightarrow$ [動作, 対象, 感情 $]$ [動作, 対象] $\rightarrow$ [時間, 空間, 感情] (例 4 ）買う，義理チョコ[動作，対象］＼cjkstart困る[感情］

Nanbaら [Nanba 2013:b]は, 英語旅行ブログデータ ベースから，旅のノウハウについて記述された旅行ブ ログエントリを自動検出する手法を提案している。旅 のノウハウブログエントリは, 以下の 2 種類に分類で きる。

・イベントタイプエントリ：茶会への参加方法など， 旅先で参加できそうなイベントについて述べたエン トリ。このようなエントリには，そのイベントに関 する歴史, 背景, ドレスコード, 所要時間などの情 報が記述されていることが多い.

・手順タイプエントリ：「どうやって富士山に登るの か」や「どのように抺み焼きを食べるのか」などの 手順について記述されているエントリ.

上記の分類を考慮し，手がかり語を用いた機械学習に 基づくノウハウブログエントリ抽出器を構築している.

\section{3 施設名などの自動抽出}

寺口ら [寺口 2011]は, Web上に投稿された自然言 語で記述された新店舗情報を自動的に抽出する手法を 提案している，新店舗情報の記述は，業種によって使 われる単語の傾向が異なる。そこで，寺口らは，店舗 の業種を自動判別し，業種別に各Webページ中に新店 舗情報が記述されているのかどうかを判定した後に， 新店舗の属性情報 (店舗名, 住所, 電話番号, 出店 日，業種）抽出している。

相良ら[相良 2007]は, HTMLタグの構造を利用し た店舗情報の収集手法を提案している。一般に, ラー メン店Aの情報 (住所, 電話番号) が既知である場合, Aの情報が含まれているWebページの中には, Aが存 在する地域の飲食店リストや, 全国の有名ラーメン店 リストといった一覧ページが含まれている可能性があ る。このようなぺージから, 新たなラーメン店を抽出
できる可能性がある。そこで，相良らは，あらかじめ 準備した特定の地域打よび業種の店舗リストを元に， そのリスト中の店舗名, 住所, 電話番号をクエリとし てWebぺージを検索し, 得られたWebページの HTML木を解析することで, 新店舗情報の収集を実現 している. 相良らと同様に, HTMLのタグ構造に着目 し, 店舗情報を抽出する研究に, 村山らの研究もある [村山 2004].

\section{3. 旅行者の行動分析}

本節では, 旅行者の行動を分析することで, 観光ルー 卜を自動的に抽出する研究について述べる。郡ら[郡 2006]は, ブログからのユーザの行動時の代表的な経 路とその文脈を抽出し，それらを地図上にマッピング することにより, 集約して提示するシステムを提案し ている。このシステムの構築は, 次の 2 つのステップ により実現されている。

1. 地名フィルタの作成

2.シーケンシャルパターンの作成

ステップ 1 では, ブログ内に現れる各地名が, 実際 に旅行者がその場所を訪れたかを文脈から判定し, 訪 れていると判定された場合はその地名を破棄する。こ の判定には，「食べる」,「見る」などの動作動詞と「到 着」などの事態性名詞, 格表現, 文節動詞の係り受け 関係についても考慮する。

ステップ 2 では, ステップ1で抽出された地名の順 序付けを行い, 地名シーケンシャルパターンを抽出す る. 以上述べた方法により, 京都の地名を含む 1,126 件の経路情報を抽出している。

長谷川ら [長谷川 2013]は, Twitter ユーザの tweet の時間的抢よび空間的連続性を考慮して, 一連の tweet をまとめ, 共有価值の高い tweet をユーザに優先的に 提示する手法を提案している. 例えば, あるユーザが 京都観光で, まず八坂神社を見学し, 次に高台寺に寄 り, 最後に清水寺に向かうというコースをとった場 合, この 3 個所を訪れる過程で投稿した一連の tweet を, ユーザが訪れた場所 (八坂神社, 高台寺, 清水寺) の連続性および tweet が投稿された日時を手がかりに まとめる.

中嶋ら [中嶋 2013]も, 長谷川らと同様に, Twitter から旅行者の観光ルートを自動抽出する手法を提案し ている. 中嶋らは, tweet集合の中から旅行者のツイー トを検出するため, Foursquare PInstagram などの SNSを利用している. Foursquare は, 位置情報に基 づいたSNSで，ユーザが初めて訪れた店舗や観光名所 
に「チェックイン」することで得点が得られる位置情報 ゲームの一種である。以下は，ある旅行者がFoursquare を利用した tweetを並べたものである([中嶋 2013]表 2 より抜粋).

1. I'm at ホテルグランティア小牧 (HOTEL GRANTIA KOMAKI)（小牧市，愛知県）

2. I'm at 清水寺 (Kiyomizu-dera Temple)（京都市, 京都府)

3. I'm at 金閣舎利殿（Golden Pavilion）(京都市, 京都府）

4. I'm at 八坂神社 (Yasaka Shrine) (京都市, 京都 府）

5. I'm at 京都マルイ（KYOTO MARUI）(京都市, 京都府）

6. I'm at 東大寺 (Todai-ji) (奈良市, 奈良県)

7. I'm at 関西国際空港 (Kansai Int'1 Airport -KIX/ RJBB）(泉佐野市, 大阪府)

この一連の tweetの atに続く名詞を抽出して並べれば, それが旅行者の観光ルートになっている. なお，中嶋 らは, 観光ルート関連以外の tweet も収集し, 手がか り語を用いて「食事」や「景観」などのカテゴリに自動分 類している.

\section{4 . 観光情報の推萀}

本節では, テキストから各地域の特色を検出した り，このような特色を利用して観光地や観光名所を自 動推薦したりする研究について述べる。

\section{1 地域の特色の検出}

奥ら [奥 2012]は，グルメ情報サイトや観光スポッ 卜情報サイトなどから収集される位置情報付きコンテ ンツに扔いて，ある地域のコンテンッ内での出現頻度 が他の地域のものよりも高い語句を地域限定語句と定 義し，このような語句を自動抽出する手法を提案して いる。地域限定語句は，例えば三重県松阪市における 「松阪牛」, 三重県伊勢市における「伊勢海老」, 奈良県 奈良市に打ける「吉野本葛」などが該当する。こうした 語句が自動的に抽出できれば，飲食店推薦サービス で，ある地域の食材を使った飲食店をユーザに推薦す ることも可能になる，奥らは，ある地域名と自己相互 情報量の高い用語で, さらにIDF(逆文書頻度)の高い ものを地域限定語として抽出している.

手塚ら [手塚 2008] は，「銘菓ひよこ」や「りんごの産 地」や「リゾート地」といった語句を入力すると，入力 語句と関連性の高い地域を地図上に表示するシステム
を構築している。例えば，「銘菓ひよこ」は福岡と東 京, 両方の土産物として知られているため, これらの 2 領域に強く関連する。また，それぞれの関連領域に は中心があり，周辺に向かって関連度は減衰していく と考えられる。ささらに, 減衰は方向性を持つことがあ

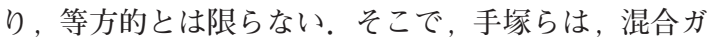
ウス分布を用いて地域性をモデル化し，土産物や郷土 料理といったオブジェクトやWebページの地域性推定 を行っている.

\section{2 観光地・観光名所の推薦}

一般に，ホテルやレストランなどの施設に対しては 施設の予約サイトやレビューサイトなどを通じて, 施 設に関するロコミ情報が得られる。他方，鳥取砂丘や 山陰海岸などの非施設については, 口コミ情報を得る のが容易ではない。そこで, 奥村ら [奥村 2010］は， 観光地における長所情報をブログから収集し, 長所を 分類する手法を提案している。 まず目的の地域に関す るブログを収集し, 次にパターン辞書を用いて情緒推 定を行い，「喜び，好ましい，期待などの情緒」と判定 された文を長所情報と考え, 抽出する. 抽出された文 を, 日本語語彙大系の用言意味属性と, 代表的な単語 の重み付け手法のひとつであるOkapi-BM25[Robertson 1994]を用いて得られた観光地の特徵的な名詞を用い, 長所情報を分類している.

上原ら [上原 2012]は，ユーザが観光名所を入力す ると, その観光名所と類似する別の観光名所を推薦 し, さらに入力された観光名所と推薦観光名所との違 いを提示するシステムを構築している. 観光名所間の 類似度を測るため, 上原らは, Yahoo! 知恵袋, Wiki pedia，ブログ，地図画像を情報源として用い，各観 光名所を様々な側面から特徴付けている。例えば, 紅 葉スポットとして有名な清水寺は，10月～11月頃に 話題に登ることが多いが，清水寺がブログやYahoo! 知恵袋で月ごとに何件言及されるかを調べることによ り, 話題性を近似值として得ている。この他, 知恵袋 のどのカテゴリのエントリで清水寺が言及されている のか, 清水寺と知恵袋やブログ中で共起頻度の高い語 なども，清水寺という観光名所の特徴として抽出す る。こうして得られた特徴集合をべクトルとみなし， ベクトル空間型モデルを用いて, 観光地間の類似度を 計算している.

\section{5 . 観光情報アクセスインターフェイス}

本節では，ユーザが観光情報にアクセスするための 様々なインターフェイスに関する研究を取り上げる。 Ishinoら [Ishino 2012]は，広島市内に打ける代表的な 


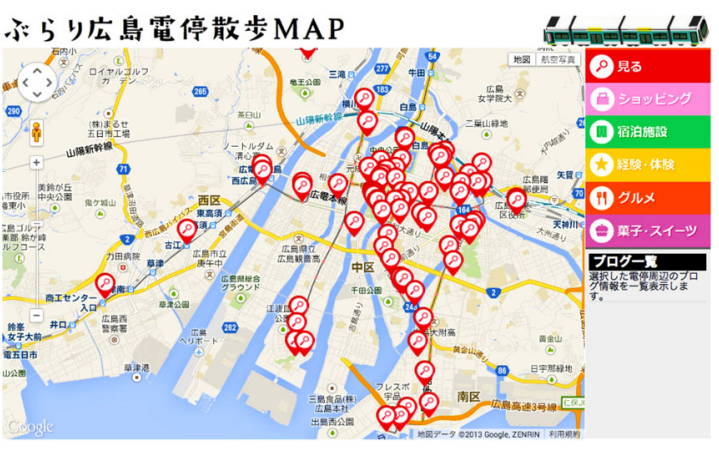

図 3 ぶらり広島電停散歩 MAP

移動手段で観光客の利用も多い路面電車に着目し, 路 面電車の駅(電停)周辺の観光情報について記述された ブログエントリ (電停ブログ)を自動検出するシステム を構築している。ささら, ブログの位置情報を人手で 判定し，地図上にマッピングしている。図 3 は，この システムの動作例である。このシステムでは, 各電停 ブログエントリを「見る」「ショッピング」「宿泊施設」 「経験・体験」「グルメ」の 5 種類のタイプに分類し, 地 図上にマッピングされた電停ブログエントリをタイプ ごとに閲覧することができる。なお，このシステム は，現在，広島市とRCC中国放送が運営している $\mathrm{p} 2$ walkerという広島市観光ポータル上で「ぶらり広島電 停散歩MAP」として公開されている (http://p2walker.jp/ peace/ja/blog/).

テキスト形式の観光情報を地図以外の媒体に対応付 けたこの他の研究に, 石野ら[石野 2012]のものがあ る。石野らは, 「るるぶ」などの紙媒体の旅行ガイド ブックを電子化したものに, 旅行ブログエントリや Yahoo! 知恵袋を自動的に対応付けるシステムを構築 している。このシステムを用いることで, 旅行者は, 基本的な情報は旅行ガイドブックから, また, 旅行者 の経験に基づく多様な情報は, 旅行ガイドブックに対 応付けられた旅行ブログエントリや, 質問応答コンテ ンツから得ることができる。

\section{6 ．地理情報検索システム}

Web検索エンジンへの全アクセス数の $20 \%$ 近くは 特定の場所に関係する問い合わせであると言われてお り [Sanderson 2004，Gravano 2003]，位置に関係する 問い合わせに的確に応えることはWeb検索エンジンに とって重要な課題となっている。本節では，地理情報 検索に関する研究を取り上げる。

戸田ら [戸田 2009]は, 地理情報検索に特化したス ニペットの生成法を提案している。一般的な情報検索 システムでは, 検索結果が検索クエリに適合している
かどうかの判断をユーザが容易に行えるようにするた め, 原文中に出現する検索クエリの周辺の文字列が検 索結果としてユーザに提示される。しかし, 地理情報 検索の場合, 入力クエリは緯度と経度の座標として与 えられるため, 従来手法ではスニペットが生成できな い.また，仮にクエリを座標ではなく文字列(地名)と して与えた場合でも，その文字列が検索結果の文書中 に含まれない可能性がある。 そこで, 戸田らは, 入力 クエリおよび文書中の地理表現をすべて緯度, 経度情 報に変換し, クエリと関連する表現を特定した上でス ニペットを生成している。

従来の地理情報検索システムを改良するこの他の研 究に, 安田らのもの[安田 2008]がある. 従来の地理 情報検索システムでは, 「東京都」のように大きな領域 を示す表現を含む文書も,「東京都新宿区歌舞伎町」の ように詳細な領域を含む文書も, クエリで指定される 範囲に含まれていれば同等に扱われていた。しかし， ユーザが「東京都新宿区歌舞伎町」を知りたい場合に は, 後者の情報について言及する文書を優先的に提示 する必要がある。そこで, 安田らは, 文書中の地名表 現が含意する広さを効果的にランキングに反映させる 手法を提案している.

\section{7. おわりに}

本稿では, 観光情報の自動編箱に関する研究動向を 概観した。本稿以外にも, 観光情報の自動編纂に関す る情報源がいくつかある。1 節でも述べたが, 著者ら のサーベイ論文[Nanba 2012]は，2012年時点での主 に海外の研究動向について紹介している. 情報処理学 会誌Vol.53, No.11は,「観光情報学」というテーマの 特集号である。また，人工知能学会誌 Vol.26, No. 3 は「観光と知能情報」の特集号である。この特集号の斎 藤による解説記事[斎藤 2011] も, この分野の研究動 向を知る上で有力な情報源である. 川村らの解説記事 [川村 2010]では，2010年時点での海外の動向も含ん だ観光情報学の概要が分かる. この他, 観光情報学会 誌「観光と情報」が2005年より年一回発行されており， 観光情報に関する幅広い研究動向を知ることができ る.

\section{参 考 文 献}

[Nanba 2012] Nanba, H., Ishino, A., and Takezawa, T., Automatic Compilation of Travel Information from Texts: A Survey, Theory and Applications for Advanced Text Mining, Sakurai, S. (Eds.), INTECH, 2012.

[岡本 2010］岡本昌之, 菊池匡晃, ブログからの地域イベ ント情報抽出，情報処理，Vol.51，No.1，pp.14-17， 2010. 
[Frantsi 1996] Frantsi, K. and Ananiadou, S., Extracting Nested Colocations, Proceedings of International Conference on Computational Linguistics, pp.41-46, 1996.

[藤坂 2010] 藤坂達也, 李龍, 角谷和俊, 地域イベント発見 のためのジオタグ付マイクロブログを用いたノーマル パターン検出手法, 平成 22 年度情報処理学会関西支 部大会, 2010 .

[吉田 2009] 吉田将人, 福原知宏, 増田英考, ブログ記事 とWebページを用いたイベント情報抽出手法の提案， 情報処理学会研究報告, デジタルドキュメント, Vol. 2009, No.35, pp.37-44, 2009.

[Tanaka 2005] Tanaka-Ishii K. and Nakagawa H., A Multilingual Usage Consultation Tool Based on Internet Searching - More than search engine, Less than QA - , Proceedings of the $14^{\text {th }}$ International World Wide Web Conference, pp.363-371, 2005.

[Nanba 2013:a] Nanba, H., Saito, R., Ishino, A., and Takezawa, T., Automatic Extraction of Event Information from Newspaper Articles and Web Pages. ICADL 2013, LNCS 8279, pp.171-175, 2013.

[阿部 2009] 阿部修也, 江口萌, 隅田飛鳥, 大崎梓, 乾健 太郎，みんなの経験：ブログから抽出したイベントお よびセンチメントのDB化. 言語処理学会第15回年次 大会, pp.296-299, 2009.

[倉島 2008] 倉島健, 藤村考, 奥田秀範 : 大規模テキスト からの経験マイニング, 第19回データ工学ワークショッ プ, 2008 .

[Nanba 2013:b] Nanba, H., Douke, S., and Takezawa, T., Automatic Identification of Know - How Blog Entries from a Travel Blog Database, International Conference on Advanced Tourism Informatics, 2013.

[寺口 2011］寺口敏生, 田中成典, 西江将男, Web リソー スと地理情報を活用した新店舗情報の自動収集に関す る研究, 知能と情報, Vol.23, No.4, pp.411-427, 2011.

[相良 2007］相良毅, 喜連川優, Webからの効率的な新規 店舗の発見・登録支援手法, 情報処理学会論文誌デー タベース, Vol.48, No.SIG 11, pp.49-57, 2007.

[村山 2004] 村山紀文, 南野朋之, 奥村学, メタデータ付 与のための住所録自動生成, 情報処理学会研究報告 自 然言語処理, Vol.2004, No.73, pp.41-47, 2004.

[郡 2006] 郡宏志, 服部峻, 手塚太郎, 田島敬史, 田中克 己,ブログからのビジターの代表的な行動経路とその コンテキストの抽出, 情報処理学会研究報告, データ ベース・システム, Vol.2006, No.78, pp.35-42, 2006.

[長谷川 2013] 長谷川馨亮, 馬強, 吉川正俊 : 行動の時空 間連続性とコンテンツの共有価值を考慮した観光ツ イートの組織化, 第 5 回データ工学と情報マネジメン トに関するフォーラム, 2013.

[中嶋 2013] 中嶋勇人, 新妻弘崇, 太田学, 位置情報付き ツイートを利用した観光ルート推薦, 情報処理学会研 究報告, データベース・システム, Vol.2013-DBS158, No.28, pp.1-6, 2013.

[奥 2012］奥健太, 西崎剛司, 服部文夫, 地域限定性スコア に基づく位置情報付きコンテンツからの地域限定語句 の抽出, 情報処理学会論文誌 データベース, Vol.5,
No.3, pp.97-116, 2012.

[手塚 2008] 手塚太郎, 近藤浩之, 田中克己, 混合ガウス 分布を用いたウェブコンテンツの地域性推定とオブ ジェクトレベルローカルサーチ, 情報処理学会論文誌 データベース, Vol.1, No.1, pp.13-25, 2008.

[奥村 2010］奥村秀人, 徳久雅人, 村上仁一, 村田真樹, 観 光地に対する長所情報の収集と分類の試み, 電子情報 通信学会技術研究報告, 思考と言語, Vol.110, No.244, pp.25-30, 2010.

[Robertson 1994] Robertson, S.E., Walker, S., Jones, S., Hancock- Beaulieu, M.M., and Gatford, M., Okapi at TREC -3 , Proceedings of the $3^{\text {rd }}$ Text Retrieval Conference, 1994.

[上原 2012］上原尚, 嶋田和孝, 遠藤勉, Web 上に混在す る観光情報を活用した観光地推薦システム, 電子情報 通信学会研究報告, 言語理解とコミュニケーション, Vol.112, No.367, pp.13-18, 2012.

[Ishino 2012] Ishino, A., Nanba, H., and Takezawa, T., Construction of a System for Providing Travel Information along Hiroden Streetcar Lines, Proceedings of the $3^{\text {rd }}$ IIAI International Conference on e-Services and Knowledge Management, 2012.

[石野 2012］石野亜耶, 藤井一輝, 藤原泰士, 前田剛, 難 波英嗣, 竹澤寿幸, 旅行ブログエントリと質問応答コ ンテンツを利用した旅行ガイドブックの情報拡張, 第 5 回Webとデータベースに関するフォーラム, 2012.

[Sanderson 2004] Sanderson, M. and Kohler, J., Analyzing Geographic Queries, Proceedings of SIGIR2004 Workshop on Geographic Information Retrieval, 2004.

[Gravano 2003] Gravano, L., Hatzivassiloglou, V., and Lichtenstein, R., Categorizing Web Queries According to Geographical Locality, Proceedings of the $12^{\text {th }}$ International Conference on Information and Knowledge Management, pp.325-333, 2003.

[戸田 2009] 戸田浩之, 安田宜仁, 奥村学, 松浦由美子, 片 岡良治, 地理情報検索のためのスニペット生成法, 人 工知能学会論文誌, Vol.24, No.6, pp.494-506, 2009.

[安田 2008] 安田宜仁, 戸田浩之, 検索位置のごく周辺を 対象とした地理情報検索, 人工知能学会論文誌, Vol.23, No.5, pp.364-373, 2008.

[斎藤 2011］斎藤一,Webに抢ける観光情報提供と分析, 人 工知能学会誌, Vol.26, No.3, pp.234-239, 2011.

[川村 2010］川村秀憲, 鈴木恵二, 山本雅人, 松原仁, 新 しい○○学: 2. 観光情報学, 情報処理, Vol.51, No.6, pp. $642-648,2010$.

(2014年 1 月 6 日 受付) 


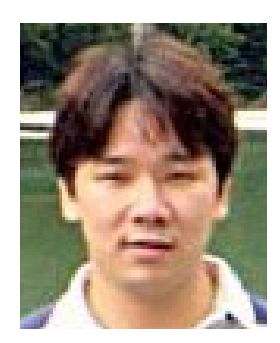

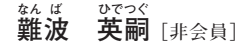

1996年東京理科大学理工学部電気 工学科卒業. 2001年北陸先端科学技 術大学院大学情報科学研究科博士後期 課程修了。同年, 日本学術振興会特別 研究員. 2002年東京工業大学精密工 学研究所助手. 同年, 広島市立大学情 報科学部講師。2010年広島市立大学 大学院情報科学研究科准教授. 現在に 至る。博士 (情報科学). 言語処理学 会, 情報処理学会, 人工知能学会, 地 理情報システム学会, ACL, ACM各 会員. 